\title{
PREVALENCE OF DEPRESSION IN THE ELDERLY POPULATION OF MANISA AND RELATED RISK FACTORS
}

\section{Abstract}

Turkish Journal of Geriatrics DOI: $10.31086 /$ tjgeri.2018.65 2018;21 (4):579-587

- Beyhan CENGIZ ÖZYURT ${ }^{1}$

- Hüseyin ELBi ${ }^{2}$

- Müjde SERIFHAN ${ }^{3}$

Introduction: The present study aimed to determine the prevalence of depressive symptoms in elderly people living in Manisa and to reveal the possible risk factors.

Materials and Method: The population of this cross-sectional study included 17760 elderly people living in the Manisa Celal Bayar University Health Education and Research District in 2017. The sample size of the study was calculated as 546 using Epi Info 7.0 software. Sample selection was performed by a simple random sampling method of the records of Manisa Provincial Public Health Directorate. The data were collected by authors, and the participation ratio was $97.8 \%(n=534)$. The Katz Index of Independence in Activities of Daily Living and Geriatric Depression Scale were used as data collection tools, in addition to a sociodemographic form. The data were analyzed by using descriptive statistics, univariate and multivariate Odds ratios (with logistic regression analysis).

Results: The mean age of the participants was $72.70 \pm 6.35$ years. Of note, $56.3 \%$ of the elderly participants were women, $44.3 \%$ were primary school graduates and $19.6 \%$ were living alone. Moreover, $78.6 \%$ of them had at least one chronic disease requiring continuous medication. The prevalence of depressive symptoms was $32.8 \%$.

Conclusion: Multivariate analyses indicated that the prevalence of depressive symptoms is more likely higher in individuals living alone and in those who are dependent on others for daily life activities. Additionally, negative expenditure income balance, perceived annual change in health status, history of previous psychiatric disease and history of abuse significantly increase the prevalence of depressive symptoms.

Keywords: Aged; Depression; Prevalence

ARAŞTIRMA

CORRESPONDANCE

Beyhan CENGIZ ÖZYURT

Manisa Celal Bayar University, Faculty of Medicine, Department of Public Health, Manisa, Turkey

\section{Phone: 02362338586}

e-mail: beyhanozyur@hotmail.com

Received: 15/10/2018

Accepted: $11 / 12 / 2018$

1 Manisa Celal Bayar University, Faculty of Medicine, Department of Public Health,

Manisa, Turkey

2 Manisa Celal Bayar University, Faculty of Medicine, Department of Familt Medicine, Manisa, Turkey

${ }^{3}$ Manisa Provincial Health Directorate, Şehzadeler District Health Directorate, Manisa, Turkey

\section{MANISA'DA YAŞLILARDA DEPRESIF BELIRTI PREVALANSI VE íLiŞKILI RISK FAKTÖRLERi}

\section{$\ddot{O ̈ z}$}

Giriş: Bu çalışmada Manisa'da yaşayan yaşılıarda depresif belirti sıklığını saptamak ve olası risk faktörlerini ortaya çıkarmak amaçlanmıştır.

Gereç ve Yöntem: Kesitsel tipteki çalışmanın evreni Mart-Nisan 2017'de Manisa Celal Bayar Üniversitesi Sağlık Eğitim Araştırma Bölgesi Toplum Sağlığı Merkezi bölgesinde yaşayan 17760 yaşııdan oluşmuştur. Araştırmanın örneklem büyüklüğü Epi info 7.0 programı kullanılarak hesaplanmış ve 546 yaşlı olarak belirlenmiştir. Çalışmaya alınacak yaşılar Manisa İ Halk Sağlığı Müdürlüğü kayıtlarından basit rastgele örnekleme yöntemi ile seçilmiştir. Veriler yüz yüze görüşülerek toplanmıştır. Katılım oranı \%97.8 $(n=534)$ olarak gerçekleşmiştir. Katılımcılara sosyodemografik veri formu, Katz Günlük Yaşam Aktiviteleri Ölçeği ve Geriatrik Depresyon Ölçeği (GDS-30) veri toplama aracı olarak uygulanmıştır. Elde edilen veriler betimleyici istatistikler, tek değişkenli ve çok değişkenli (lojistik regresyon analizleri ile) Odds Oranları hesaplanarak değerlendirilmiştir.

Bulgular: Araştırmaya katılanların yaş ortalaması $72.70 \pm 6.35$ 'dir. Araştırmaya katılan yaşılırın \%56.3'ü kadın, \%44.3'ü ilkokul mezunu ve \%19.6'sı yalnız yaşamaktadır. \%78.6'sında sürekli ilaç kullanmayı gerektiren en az bir kronik hastalık vardır. Depresif belirti sıklığı ise \%32.8'dir.

Sonuç: Çok değişkenli analizlerde, yalnız yaşayan, günlük yaşam aktivitelerinde başkasına bağımlı olan; bir önceki yıla göre sağlık durumunun daha olumsuz olduğunu belirten; son bir yılda kötü muameleye maruz kalan; geliri giderine göre daha az olan ve daha önce geçirilmiş psikiyatrik hastalık öyküsü olanlarda, depresif belirti sıklığının daha fazla olduğu saptanmıştır.

Anahtar sözcükler: Yaşlı; Depresyon; Prevalans 


\section{INTRODUCTION}

Life expectancy has increased due to advances in medicine and improvements in living conditions, leading to growth of the elderly population, from $5.6 \%$ in 2005 to $8.7 \%$ in 2018 . According to population projections, the proportion of the elderly population is estimated to reach $16.3 \%$ in 2040 and $22.6 \%$ in 2060 (1). Mental health and well-being are as important in old age as at any other time of life. Depression in the elderly has become an important public health problem as the elderly population has grown in Turkey (2).

Older adult's biological structure, life experiences and coping with problems, physical health conditions, economic conditions, status in society and living alone affect the psychological health condition and so depression may occur more frequently in the elderly (3).

The World Health Organization (WHO) has reported that the most common mental disorder in older adults is depression, which affects approximately $7 \%$ of the world's elderly population, and clinically significant depressive symptoms have been reported in 15\% of older adults (4). Depression prevalence rates differ among countries: a recent population-based study found that $41.8 \%$ of the elderly had depressive symptoms in Ethiopia (5), 40.0\% in South Africa (6) and $42.7 \%$ in India (7). Globally, clinically significant depressive symptoms exist in one in every eight elderly individuals living in the community; however, the depression rate is higher in inpatient older adults and in those who reside in nursing homes $(8,9)$. In a study conducted in Turkey, $68.9 \%$ of individuals living in nursing homes and $27.9 \%$ of those living at home were found to have depression (10). Another study conducted in a nursing home reported that $47.4 \%$ of the elderly had depressive symptoms and $39 \%$ had diagnosed depression (11). Although studies have shown that the depression rate is high in individuals living in nursing homes, depression is observed frequently in the elderly living in the community as well. Additionally, depression in old age may decrease individual physical abilities and quality of life and increase the risk of suicide and premature death, unless it is diagnosed and treated early (9).

Many factors play a role in the emergence of depression in the elderly, including female sex; low socioeconomic status; living alone; presence of chronic disease; physical, verbal and economical abuse and needing assistance in activities of daily living (ADL) (5-7,10-12). Therefore, the early recognition of depressive symptoms and the determination of risk factors are important in the elderly. The aim of this study was to determine the prevalence and risk factors of depressive symptoms in elderly people living in Manisa, Turkey.

\section{MATERIALS AND METHOD}

This is a cross-sectional study conducted in individuals aged 65 years and older living in the Manisa Celal Bayar University (CBU) Health Education and Research District in March-April 2017. The elderly population (aged 65 years and over) living in this district included 17760 individuals, as recorded in the health district registry. The minimum sample size was calculated as 546 with $95 \%$ confidence rate, $5 \%$ maximum type 1 error and $50 \%$ event prevalence using Epi Info 7.0 software. Elderly individuals were randomly selected from the records of the health district registry of Manisa Provincial Public Health Directorate. Data were collected by a battery of questionnaires by interviewer administration at the respondents' homes. On the planned date of the visits, the older adults who could not be contacted at home were re-visited the next day at a different time. Individuals with cognitive 
dysfunctions, such as pre-diagnosed dementia, were excluded from the study. Additionally, adequacy of cognitive skills of the older adults was evaluated using a simple memory test based on word list recall at the beginning and middle of the interview. Five elderly individuals could not be contacted at home and seven declined to participate in the study. The overall rate of participation was $97.8 \%(n=534)$.

The existence of depressive symptoms was the dependent variable, whereas sociodemographic characteristics such as age, sex, educational status, marital status, income perception and migration status; verbal and physical abuse; self and family history of any psychiatric diagnosis; presence of any comorbid chronic illness and ADL measured by the Katz Index of Independence were predictor (independent) variables in this study.

\section{Data collection}

Data were collected via face-to-face interviews (interviewer administration) in the homes of the elderly during March-April 2017. The person closest to the working time at birth (in months/ days) was included in the study when there was more than one person aged $\geq 65$ in the home. Ethical approval was obtained from Manisa CBU Health Sciences Ethics Committee and Manisa Public Health Directorate. The study data were collected using the Katz Index of Independence in ADL and Geriatric Depression Scale (GDS) in addition to a sociodemographic questionnaire.

\section{Katz Index of Independence in ADL}

The Katz Index of Independence in ADL measures the level of dependence of the elderly in performing daily activities. The Katz Index comprises movement, excretion, washing, dressing, toilet needs and nutritional activities $(13,14)$. Each activity level is categorised as totally dependent (0-6 points), partially dependent (7-12 points) or independent (13-18 points).

\section{Geriatric Depression Scale}

The GDS measures the level of depressive symptoms and severity changes in individuals over 60 years of age with no apparent hearing difficulties and no moderate-to-severe dementia. However, it excludes somatic complaints and sexual function related to depression, as well as expectations for the future. The GDS is a screening tool for depressive mood that evaluates patients for depression in the prior week and comprises 30 questions (15). It can be filled in either by self-application or by interviewer assistance and administration. The overall possible score ranges from 0 to 30 points. The cut-off point of the scale is $13 / 14$, and there is a high likelihood of depression in individuals who score above this cut-off point. Turkish validity results were published by Sagduyu A. et al (16).

\section{Statistical analysis}

The statistical analyses were comprised of descriptive statistics (number, percentage distribution, mean and standard deviation) and logistic regression analyses (Backward Wald model) in order to investigate the relationships between depression and the predictor variables.

\section{RESULTS}

The mean age of the older adults was $72.70 \pm 6.35$ years. Of note, $56.4 \%$ of the elderly participants were women, $44.4 \%$ were primary school graduates, $60.9 \%$ were married, $32.4 \%$ had greater expenses than their income and $36.1 \%$ had immigrated into the district (Table 1).

Thirty-two percent of the elderly participants had depressive symptoms based on a score of 14 or above in the GDS (mean GDS score, 12.15 \pm 6.86 ). Overall, $8.4 \%$ of the participants stated that they had previously been diagnosed with a mental illness and $13.9 \%$ of them stated that they had a family history of mental illness in first-degree relatives (Table 2). 
Table 1. Distribution by sociodemographic characteristics.

\begin{tabular}{|c|c|c|}
\hline Variables & $\mathrm{n}$ & $\%$ \\
\hline \multicolumn{3}{|l|}{ Age } \\
\hline $65-69$ & 202 & 37.8 \\
\hline $70-74$ & 156 & 29.2 \\
\hline 75-79 & 96 & 18.0 \\
\hline $80+$ & 80 & 15.0 \\
\hline \multicolumn{3}{|l|}{ Gender } \\
\hline Male & 233 & 43.6 \\
\hline Female & 301 & 56.4 \\
\hline \multicolumn{3}{|l|}{ Education } \\
\hline Illiteracy & 87 & 16.3 \\
\hline Literacy & 110 & 20.6 \\
\hline Primary school & 237 & 44.4 \\
\hline Secondary school & 38 & 7.1 \\
\hline High school & 44 & 8.2 \\
\hline University & 18 & 3.4 \\
\hline \multicolumn{3}{|l|}{ Marital status } \\
\hline Married & 325 & 60.9 \\
\hline Single & 13 & 2.4 \\
\hline Widow & 185 & 34.6 \\
\hline Divorced & 11 & 2.1 \\
\hline \multicolumn{3}{|l|}{ Income } \\
\hline Low & 173 & 32.4 \\
\hline Middle & 289 & 54.1 \\
\hline High & 72 & 13.5 \\
\hline \multicolumn{3}{|l|}{ Immigration } \\
\hline No & 341 & 63.9 \\
\hline Yes & 193 & 36.1 \\
\hline
\end{tabular}

Table 3 shows the factors associated with the presence of depressive symptoms. Living in rural and semi-urban areas, female sex, having no formal education, living alone, not being married, not having income, having chronic disease, a history of psychiatric disease and having poor health perceptions were risk factors of depression. The risk of depressive symptoms was high in the elderly 
who had been subjected to maltreatment (abuse) in the last year and was found to be dependent on the ADL according to Katz Index. These differences were statistically significant $(p<0.05)$.

Table 2. Distribution of participants by depressive symptoms and psychiatric disorders.

\begin{tabular}{|l|r|r|}
\hline Variable & $\mathbf{n}$ & $\%$ \\
\hline Presence of depressive symptoms & & \\
\hline Yes * & 175 & 32.8 \\
\hline No & 359 & 67.2 \\
\hline Previously diagnosed mental illness & & \\
\hline Yes & 44 & 8.4 \\
\hline No & 480 & 91.6 \\
\hline Family history of mental illness & & 13.9 \\
\hline Yes & 73 & 86.1 \\
\hline No & 451 & \\
\hline
\end{tabular}

* The Geriatric Depression Scale (GDS) point 14 and over

There was a weak positive correlation between age and GDS score $(r=0.13, p=0.01)$ and a moderate positive correlation between age and Katz Index score $(r=0.41, p<0.001)$.

A logistic regression model was developed to evaluate the independent risks of the different variables affecting depressive symptoms. Correlations between the variables found to be effective alone were evaluated, and it was decided to include those variables with a higher correlation and greater effect on depressive symptoms. The region where they lived, sex, income status, with whom they were living, addiction status, presence of chronic disease, health status compared with the previous year, ill treatment in the last year and history of psychiatric disease were entered into the model. In the model, the prevalence of depressive symptoms was 3.06 times greater $(95 \%$ $\mathrm{Cl}$ 1.54-6.09) in those living alone, 2.75 times (95\% $\mathrm{Cl} 1.71-4.43)$ greater in those who stated that their health status was worse than the previous year and 4.58 times $(95 \% \mathrm{Cl} 2.06-10.16)$ greater in those who had been subjected to neglect-abuse in the last year. A 2.89-fold risk (95\% Cl 1.02-8.21) of depression was found in patients with a history of psychiatric disease (Table 4). 
Table 3. Univariate analysis between depression and sociodemographic-economic characteristics.

\begin{tabular}{|c|c|c|c|}
\hline Variables & $\begin{array}{r}\text { Presence of } \\
\text { depressive } \\
\text { symptoms } \\
\%\end{array}$ & OR $(\% 95 \mathrm{Cl})^{\star \star *}$ & $\mathrm{p}$ \\
\hline \multicolumn{4}{|l|}{ Region (Ref: Urban) ${ }^{\star \star \star}$} \\
\hline Rural $(n=232)$ & 36.2 & $1.91(1.25-2.92)$ & $<0.001$ \\
\hline Semi-urban $(n=101)$ & 44.6 & $2.70(1.62-4.51)$ & \\
\hline \multicolumn{4}{|l|}{ Age (Ref: $65-74)$} \\
\hline 75 and over $(n=176)$ & 37.5 & $1.37(0.93-2.00)$ & 0.103 \\
\hline \multicolumn{4}{|l|}{ Gender (Ref: Male) } \\
\hline Female $(n=301)$ & 38.5 & $1.84(1.27-2.69)$ & 0.001 \\
\hline \multicolumn{4}{|l|}{ Marital status (Ref: Married) } \\
\hline Other $(n=209)$ & 45.5 & $2.55(1.76-3.69)$ & $<0.001$ \\
\hline \multicolumn{4}{|c|}{ Education (Ref: Primary school and over) } \\
\hline Illetaracy/Literacy $(n=197)$ & 47.2 & $2.78(1.91-4.04)$ & $<0.001$ \\
\hline \multicolumn{4}{|c|}{ People alive (Ref: It lives with someone) } \\
\hline Alone $(n=105)$ & 43.8 & $1.76(1.13-2.73)$ & 0.010 \\
\hline \multicolumn{4}{|l|}{ Income (Ref: Good) } \\
\hline Bad $(n=173)$ & 49.7 & $3.02(2.06-4.42)$ & $<0.001$ \\
\hline \multicolumn{4}{|c|}{ Health status according to previous year (Ref: Good) } \\
\hline Same $(n=231)$ & 20.3 & $1.06(0.51-2.22)$ & $<0.001$ \\
\hline Bad $(n=238)$ & 49.2 & $4.04(1.99-8.18)$ & \\
\hline \multicolumn{4}{|l|}{ Chronic illness (Ref: No ) } \\
\hline Yes $(n=420)$ & 36.0 & $1.91(1.16-3.15)$ & 0.009 \\
\hline \multicolumn{4}{|c|}{ History of psychiatric disease (Ref: No ) } \\
\hline Yes $(n=44)$ & 70.4 & $4.23(1.79-9.98)$ & $<0.001$ \\
\hline \multicolumn{4}{|c|}{ Maltreatment (abuse) in the last year (Ref: No) } \\
\hline Yes $(n=71)$ & 60.6 & $3.75(2.24-6.30)$ & $<0.001$ \\
\hline \multicolumn{4}{|c|}{ According to ADL (Ref: Independent) } \\
\hline Dependent $(n=145)$ & 58.6 & $4.58(3.05-6.87)$ & $<0.001$ \\
\hline
\end{tabular}

* The Geriatric Depression Scale (GDS) point 14 and over ; ${ }^{* \star O R: ~ O d d s ~ R a t i o, ~}{ }^{* \star \star R e f: ~ R e f e r e n c e ~}$ 
Table 4. Factors associated with the presence of depressive symptom according to the last model of reduced logistic regression.*

\begin{tabular}{lr}
\hline Variable & Multivariate analysis OR value (95\% CI) \\
\hline Living alone & $3.06(1.54-6.09)$ \\
Being dependent on others in daily living activities & $4.18(2.39-7.31)$ \\
Poorer health compared to the previous year & $2.75(1.71-4.43)$ \\
Less than the amount of income from expenses & $2.54(1.45-4.43)$ \\
Abuse in the last year & $4.58(2.06-10.16)$ \\
A history of previous psychiatric illness & $2.89(1.02-8.21)$ \\
\hline
\end{tabular}

* Model variables; Changes in the region, gender, lifestyle, addiction status, presence of chronic diseases, health status compared to the previous year, income-expenditure situation, last year ill-treatment, history of psychiatric disease

\section{DISCUSSION}

The prevalence and risk factors of depression in the elderly vary in different studies in Turkey (10$12,17,18)$. In addition, studies vary in terms of the setting, for example, in the community or in a nursing home (8-11). Population-based representative recent studies are rather scarce in Turkey. This study shows the prevalence of depressive symptoms in a community-based investigation.

In the present study, the prevalence of depressive symptoms was $32.8 \%$ in the elderly. The prevalence of depression varies greatly among studies conducted with geriatric depression screening scales. The frequency of depressive symptoms in previous studies was 18.5\%-56.6\% in community-based investigations, in Turkey $(11,12,17,18)$. A community-based study conducted in South Africa using the GDS found depressive symptoms in $40 \%$ of the elderly (6). In contrary, depression prevalence in the elderly population is lower (range 9.0\% - 11.0\%) in developed countries than underdeveloped countries $(19,20)$. This higher depression rate seen in the underdeveloped countries may be attributed to the economic deprivation that might affect older adults more than the young adults. The rate of depressive symptoms (i.e. 32.8\%) in older adults in our study is a consistent figure that falls between the rates of economically developed and under-developed communities.

Our study results showed that, depressive symptoms were higher in the elderly who were socioeconomically disadvantaged and who had a lack of social support. Consistent with our findings, it was observed in the literature that depressive symptoms were more common in elderly women who did not have education, who had low socioeconomic status and who were living alone (8-12). Our results also indicated that having any disability, previous depression, poor health status, poor self-perception of health status and female gender are directly related to depressive mood in older adults, hence these findings were supported by a meta-analysis (21). On the other hand, we found that depressive symptoms were three times higher [3.06 (Cl 95\%:1.54-6.09)] in the elderly who were living alone. In a recent longitudinal study conducted in Netherlands it was concluded that the loneliness negatively affected the prognosis of depression (22).

We found that the frequency of depressive symptoms was four times higher in elderly patients who had any chronic illness and who were physically 
dependent on others. Although the prevalence of depressive symptoms in the general population is $15 \%$, this rate rises to $25 \%$ in the elderly with chronic disease $(9,23)$. Physical health deterioration and having chronic disease limits the daily living activities of the elderly, making them dependent on others. This would negatively affect their selfrole and dignity in life, leading to an increase in depressive symptoms $(9,23)$.

History of maltreatment (4.58 times risk of depression) affected the frequency of depressive symptoms the most. Abuse of the elderly, which is a preventable problem, hurts the elderly and leads to psychosocial problems (24). There is a strong relationship between depression and abuse of the elderly; therefore, both problems are considered risk factors for each other $(24,25)$.

\section{Limitations}

The limitations of the present study naturally include those related with the cross-sectional design of this study. First of all, interviews were done at day time which may restrict the participation rate of the study. A second limitation of this cross sectional design is the difficulty to infer the temporal association between risk factors and the outcomes. Therefore, only an association, and not causation,

\section{REFERENCES}

1. Aksüllü N, Doğan S. Relationship of social support and depression in institutionalized and noninstitutionalized elderly. Anatolian J of Psychiatry 2004;5:76-84. (in Turkish).

2. Alexopoulos GS. Depression in the elderly. Lancet 2005;365:1961-70. (PMID:15936426).

3. Aylaz R, Akturk U, Erci B, Ozturk H, Aslan $H$. Relationship between depression and loneliness in elderly and examination of influential factors. Arch Gerontol Geriatr 2012;55(3):548-54. (PMID:22487148).

4. Blazer DG. Depression in late life: review and commentary. J Gerontol A Biol Sci Med Sci 2003;58:249-65. (PMID:12634292). can be inferred in this study. In addition to these restrictions, the type of the interviews might have biased the results more or less. Firstly, depression symptoms were measured with only a self-rated scale and no psychiatric interview was performed. Depression in elderly individuals may differ from the classical symptoms of depression and therefore depression may not be detected. Secondly an evaluation of the cognitive functions could not be performed in this study.

To conclude, depressive symptoms are seen more frequently among elderly with a lower economic status, with a history of abuse and female gender. For this reason, priority should be given to these people in order to identify and screen depression. Proper training of primary health care personnel to detect elderly depression early should be provided during health-care planning. Education about the different symptoms of elder depression, communication and interview skills with elderly and use of geriatric depression scales are important parts of this training. Thus, we consider that the growing elderly population in the community in Turkey provides an opportunity to increase the quality and efficiency of health services provided to the elderly.
5. Cole MG, Dendukuri N. Risk factors for depression among elderly community subjects: a systematic review and meta-analysis. Am J Psychiatry 2003;160:1147-56. (PMID:12777274).

6. de Sousa RD, Rodrigues AM, Gregório MJ, et al. Anxiety and depression in the portuguese older adults: prevalence and associated factors. Front Med 2017;20(4):196. (PMID:29209612).

7. Dişçigil G, Gemalmaz A, Başak F, Gürel S, Tekin N. Signs of depression in the elderly relationship between depression and sociodemographic characteristics TAF Prev Med Bull 2008;7(5):399-404. (in Turkish). 
8. Dong $X$, Simon MA, Odwazny $R$, Gorbien $M$. Depression and elder abuse and neglect among a community-dwelling Chinese elderly population. J Elder Abuse Negl 2008;20:25-41. (PMID:18551905).

9. Eker E, Utucu N. Physical disorders and depression in the elderly population. Akademik Geriatri Dergisi 2009;1:90-97. (in Turkish).

10. Ellison JM, Kyomen HH, Harper DG. Depression in later life: an overview with treatment recommendations. Psychiatr Clin North Am 2012;35:203-29. (PMID:22370499).

11. Gul HL, Evcili G, Karadas O, Gül ES. Geriatric depression and associated risk factors: the level of depression symptom at elderly living in nursing home. J Clin Anal Med 2012;3:308-10. (in Turkish).

12. Güz H, Çolak EG. Psychiatric illnesses found in old age. T Klin J Psychiatry 2002;3:63-74. (in Turkish).

13. Holvast F, Burger $H$, de Waal MM, van Marwijk HW, Comijs HC, Verhaak PF. Loneliness is associated with poor prognosis in late-life depression: longitudinal analysis of the Netherlands study of depression in older persons. J Affect Disord 2015;185:1-7. (PMID:26142687).

14. Katz S, Ford AB, Maskowitz RW, Jackson BA, Jaffe MW. Studies of illness in the aged: the index of ADL: a standardized measure of biological and psychosocial function. JAMA 1963;185:914-9. (PMID:14044222).

15. Lok N. Elder abuse and neglect in Turkey: a systematic review. Current Approaches in Psychiatry 2015;7(2):149-156. (in Turkish).

16. Mirkena Y, Reta MM, Haile K, Nassir Z, Sisay MM. Prevalence of depression and associated factors among older adults at ambo town, Oromia region, Ethiopia. BMC Psychiatry 2018;18(1):1-7. (PMID:30336773).
17. Padayacheya U, Ramlalla S, Chipps J. Depression in older adults: prevalence and risk factors in a primary health care sample. S Afr Fam Pract 2017;59(2):61-6.

18. Sagduyu A. The geriatric depression scale: a reliability and validity study in comparison with hamilton rating scale for depression. Turk Psikiyatri Derg 1997;8(1):38. (in Turkish).

19. Sinha SP, Shrivastava SR, Ramasamy J. Depression in an older adult rural population in India. MEDICC Rev 2013 Oct;15(4):41-4.

20. Sjöberg L, Karlsson B, Atti AR, Skoog I, Fratiglioni L, Wang HX. Prevalence of depression: Comparisons of different depression definitions in population-based samples of older adults. J Affect Disord 2017;221:12331. (PMID:28645024).

21. Tel H, Tel H, Sabancıoğulları S. Status of maintenance of activities of daily living and experience of loneliness in elder than 60 years old living at home and in institutions. Turk J Geriatrics 2006;9:34-40. (in Turkish).

22. TUIK 2017 Elderly statistics. [Internet] Available from: http://www.tuik.gov.tr/PreHaberBultenleri. do?id=24644. Accessed: 13.10.2018.

23. WHO. Mental health of older adults. [Internet] Available from: http://www.who.int/news-room/ fact-sheets/detail/mental-health-of-older-adults Accessed: 30.10.2018.

24. Yaka E, Keskinoğlu P, Uçku R, Yener GG, Tunca Z. Prevalance and risk factors of depression among community dwelling elderly. Arch Gerontol Geriatr 2014;59:150-4. (PMID:24767692).

25. Yesavage JA, Brink TL, Rose TL, et al. Development and validation of a geriatric depression screening scale: a preliminary report. J Psychiatr Res 1983;17(1):37-49. (PMID:7183759). 